\title{
Heat Resistance of Cladosporium Isolated from Laboratory Animal Facilities
}

\author{
Satoru KAWAI, Kosuke TAKATORI, and Tsuneo OHTAKI \\ Hatano Research Institute, Food and Drug Safety Center, 729-5 \\ Ochiai, Hadano-shi, Kanagawa 257, Japan
}

(Received 4 August 1989/Accepted 14 February 1990)

\begin{abstract}
Heat resistance tests for the saprophyte, Cladosporium, isolated from laboratory animal facilities were carried out. In testing the effects of moderate and high temperature conditions, $C$. sphaerospermum $(C . s)$ and C. cladosporioides $(C . c)$ were found to grow on media in temperatures less than $32^{\circ} \mathrm{C}$, but did not in temperature of $35^{\circ} \mathrm{C}$ and over. The colony diameter of Cladosporium became smalleras temperature increased. The death time of $C . s$ treated with moist heat was within $12 \mathrm{~min}$ at $48^{\circ} \mathrm{C}$ and that of $C$. $c$ was within $26 \mathrm{~min}$ at $43^{\circ} \mathrm{C}$. Both Cladosporium species could not survive for more than $1 \mathrm{~min}$ at $55^{\circ} \mathrm{C}$. On the other hand, Cladosporium treated with dry heat could not survive more than $69 \sim 12 \mathrm{~min}$ (C. s) and $39 \sim 9.5 \mathrm{~min}\left(\right.$ C. $c$ ) at $70 \sim 100^{\circ} \mathrm{C}$. From these results, it can be seen that Cladosporium was definitely sensitive to heat treatment, and the authors assume that heat is a means of prevention in laboratory animal facilities.
\end{abstract}

\section{実験動物飼育施設から分離されたCladosporium の熱抵抗性}

\author{
川合覚・高鳥浩介·大滝恒夫 \\ 財団法人食品薬品安全センター秦野研究所
}

C. sphaerospermum, C. cladosporioidesは自然 界に広く分布する代表的なCladosporium 属の腐生真 菌である。これら腐生真菌は, 食品加工環境下で本菌混 入による品質低下や，建造物および居住環境の污染を引 き起こし，精密電子機器の劣化などあらゆる分野で悪影 響を及ぼしている $[2 ， 3 ， 10 ， 12]$ 。また実験動物施設 内に扑ける落下菌検査や, 拭きとり検査でも本菌は多数 分離され，時折バリア区域内からす検出されることがあ る。C. sphaerospermum, C. cladosporioidesは生 体に対し, 直接被害を及ぼすことは少ないとされるが, 環境污染腐朽菌やアレルゲンになる可能性は十分に考兄 られ[4,10,16], 動物実験の場では, 常時本菌の存在 に注意を払ら必要がある。

今回は実験動物飼育施設に打ける防徽対策上の基礎デ 一タを得る目的で, 実験動物施設より頻繁に分離される C. sphaerospermum および C. cladosporioidesに
ついて熱抵抗性試験を実施し，その成績を報告する。

\section{材料および方法}

1 供試 Cladosporium 株：今回実験に用いた菌株 は, 当センターの実験動物施設内に打いて定期的に実施 される空中落下菌検査に加え, 動物体表拭き取り調查お よび施設内拭さとり検査の際に分離された C. sphaerospermum（以下 C. $s$ と略）10株, C. cladosporioides (以下 $C . c$ と略) 10株である。またこれら 2 種と比較の ため, ヒト病巣由来 C. carrionii (M\#1230-4株) 1 株 る用いた。

2 胞子浮遊液作製：各供試菌をポテト・デキストロー ス寒天斜面培地（日水製薬）(以下 PDA）上に接種し, $25^{\circ} \mathrm{C}, 10$ 日間培養後, $0.1 \%$ Tween 80 ・生理食塩液を 培地内に加兄, 常法 [5] に従って胞子浮遊液を作製し 
た。胞子浮遊液は改良型ノイバウェル血球計算盤を用い

て, 胞子数 $5 \sim 10 \times 10^{5} / \mathrm{ml}$ に調整した。

3 熱抵抗性試験

恒温培養增殖性試験：上記で作製した胞子浮遊液を用 い, 恒温条件下で巨大培養を行った $[11]$ 。胞子浮遊液

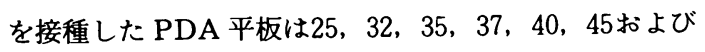
$50^{\circ} \mathrm{C}$ の各温度に設定した恒温器内で 7 日間培養後, 集落 形成の有無および集落の直径を計測した。

湿熱抵抗性試験 : 本試験には先の試験で用いた 3 菌種 21株のらち無作為に選抜した C. $s 4$ 株(No. 1 No. 4), C. $c 5$ 株（No. 1 No. 5) およびC. carrionii 1 株の 計10株を用いた。恒温水槽によって $37,40,45 ， 48 ， 50$, $52,55, お よ ひ ゙ 60$ C 保った生理食塩液 $1 \mathrm{ml}$ 内に胞子 浮遊液 $0.1 \mathrm{ml}$ を滴下した。 $1 ， 3 ， 5 ， 10 ， 30 ， 45 ， 60$, 90 および120分間処理後, 菌夜を速やかに冷却し, その 処理液の $0.1 \mathrm{ml}$ をPA 平板に接種, コンラージ棒で拡 げ，25，7 日間培養後に集落形成の有無を観察した。

晥熱抵抗性試験: 減菌万紙の中央部に胞子浮遊液 0.1 $\mathrm{ml}$ を滴下し, $37^{\circ} \mathrm{C}, 30$ 分間乾燥した。乾燥終了後, 各

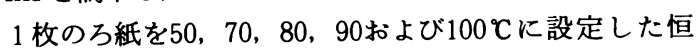
温器内で, $5,10,15,30,60,90 お よ ひ ゙ 120$ 分間処理 した。所定時間毎にそのろ紙を取り出し，PDA 平板上 に貼付, $25^{\circ} \mathrm{C}, 7$ 日間培養後集落形成の有無を観察し た。PDA 平板上に貼付したろ紙は培養開始 3 日目に剥 がし，培湌を継続した。

菌死隇の判定法 : 各熱抵抗性試験においてて所定の培養 が終了した時点で, PDA 平板上に集落が全く認められ なかったものを死减と判定し, 死减に達するまでの熱処 理時間を死减時間とした。

\section{成 綂}

1 恒温培養增殖性試験 : 培養温度を $25^{\circ}$ 亿設定した場

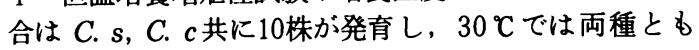
8 株が発育, $32{ }^{\circ} \mathrm{C} て ゙ は C . s 4$ 株, C. $c 3$ 株が発育した (Fig. 1)。35 37 $\mathrm{C}$ の培養温度では, C. carrioniiの みに発育が見られ，40`以上の設定では, 全ての菌株が 発育しなかった。これら各供試温度で形成された集落の 平均直径はFig. 2 に示したとおりである。C. $s$ は培養 温度 $25^{\circ} \mathrm{C}$ の場合 $23.9 \pm 3.4 \mathrm{~mm}, 30^{\circ} \mathrm{C}$ では $16.4 \pm 5.2$

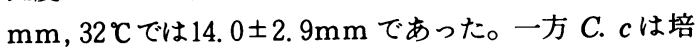
養温度 $25^{\circ} \mathrm{C}$ の場合 $34.2 \pm 6.3 \mathrm{~mm}, 30^{\circ} \mathrm{C}$ では $14.9 \pm 3.6$ $\mathrm{mm}, 32$ Cでは8. $5 \pm 0.7 \mathrm{~mm}$ であった。従って C. $c, C$. $s$ 両種は, 培養温度の上昇に伴って集落の直径が減少す る傾向を示し, 特に C. c は顕著な堿少傾向が認められ

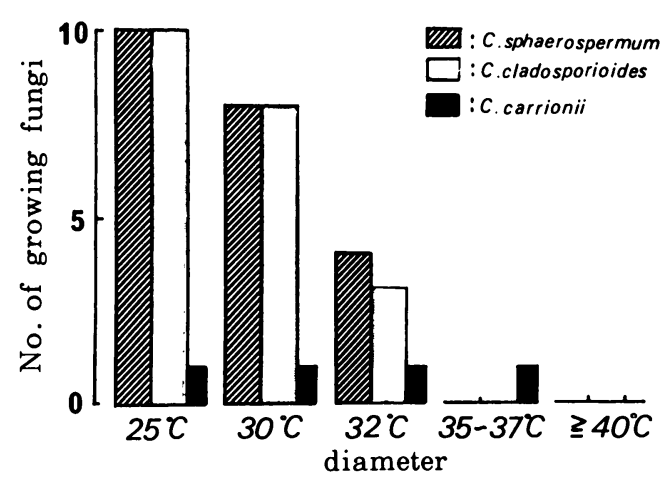

Fig. 1. Fungal growth test at different temperature

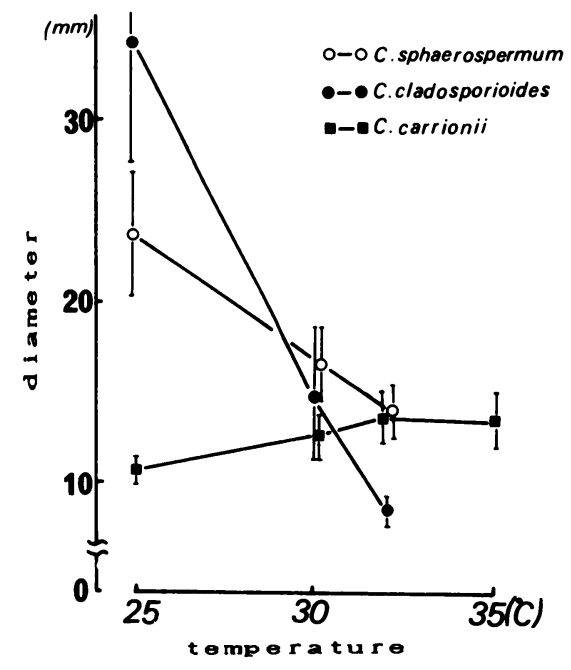

Fig. 2. The colony diameter of Cladosporium

た。これら両種に対し，C. carrioniiは, $25 \sim 35{ }^{\circ} \mathrm{C} の$ 範囲で集落の直径が増加傾向を示した。

2 湿熱抵抗性試験: 湿熱処理による C. s の平均死減 時間は， $45^{\circ}$ Cでは82.5分であったが， $48^{\circ} \mathrm{C} て ゙ は 12$ 分と著 しく短縮し, $50^{\circ} \mathrm{Cでは} 3$ 分, $52^{\circ} \mathrm{C} て ゙ は 3$ 株が 1 分以内に 死滅, そして $55^{\circ}$ C以上では 1 分以内の処理で 4 株全て死 堿した (Table 1). 一方 C. c は $43^{\circ}$ C 前後の処理で死诚 時間の短縮が顕著となり， 48 Cでは約 2 分, $52^{\circ}$ Cでは 4 株が 1 分以内に死减, そして $55{ }^{\circ} \mathrm{C}$ 以上では 5 株全て 1 分 以内の処理で死减した (Table 1)。これら2 種に対し, C. carrionii $450^{\circ} \mathrm{C}$ 以前に著明な死减時間の短縮は認 められず, 52 Cで15分, $55^{\circ}$ Cで 3 分， 60 C以上で 1 分以 内に死滅した。 すなわち今回, 供試した菌の湿熱抵抗性 には種差が認められ，C. carrionii, C. s, C. c の順で 
Table 1. Fungal survival time in moist heat test (min)

\begin{tabular}{|c|c|c|c|c|c|c|c|c|c|c|}
\hline \multirow{2}{*}{ Fungus } & \multirow[b]{2}{*}{ No. } & \multicolumn{9}{|c|}{ Temperature ${ }^{\circ} \mathrm{C}$ ) } \\
\hline & & 37 & 40 & 43 & 45 & 48 & 50 & 52 & 55 & 60 \\
\hline \multirow{5}{*}{ C. $s$} & 1 & $120<$ & $120<$ & $120<$ & 90 & 3 & 1 & $<1$ & $<1$ & $<1$ \\
\hline & 2 & $120<$ & $120<$ & $120<$ & 90 & 15 & 5 & $<1$ & $<1$ & $<1$ \\
\hline & 3 & $120<$ & $120<$ & $120<$ & 90 & 15 & 5 & $<1$ & $<1$ & $<1$ \\
\hline & 4 & $120<$ & $120<$ & $120<$ & 60 & 15 & 1 & 5 & $<1$ & $<1$ \\
\hline & $\overline{\mathrm{X}}$ & $\cdots \cdots$ & $\cdots \cdots$ & $\cdots \cdots$ & 82.5 & 12.0 & 3.0 & $\cdots \cdots$ & $\cdots \cdots$ & $\cdots \cdots$ \\
\hline \multirow[t]{6}{*}{ C. $c$} & 1 & $120<$ & 90 & ND & ND & 5 & 5 & 5 & $<1$ & $<1$ \\
\hline & 2 & $120<$ & 90 & 30 & 10 & 3 & 1 & $<1$ & $<1$ & $<1$ \\
\hline & 3 & $120<$ & 90 & 30 & 30 & 1 & 1 & $<1$ & $<1$ & $<1$ \\
\hline & 4 & $120<$ & 90 & 15 & 5 & 1 & 1 & $<1$ & $<1$ & $<1$ \\
\hline & 5 & $120<$ & 90 & 30 & 5 & 1 & 3 & $<1$ & $<1$ & $<1$ \\
\hline & $\overline{\mathbf{X}}$ & $\cdots \cdots$ & 90 & 26.3 & 12.5 & 2.2 & 2.2 & - & $\cdots \cdots$ & $\cdots \cdots$ \\
\hline \multicolumn{2}{|c|}{ C. carrionii } & $120<$ & $120<$ & $120<$ & $120<$ & 45 & 45 & 15 & 3 & $<1$ \\
\hline
\end{tabular}

$\begin{array}{ll}\text { C. } s: C . \text { sphaerospermum } & \text { C. } c: C \text {. cladosporioides }\end{array}$

Table 2. Fungal survial time in dry heat test (min)

\begin{tabular}{|c|c|c|c|c|c|c|}
\hline \multirow{2}{*}{ Fungus } & \multirow{2}{*}{ №. } & \multicolumn{5}{|c|}{ Temperature ( $\mathrm{C}$ ) } \\
\hline & & 50 & 70 & 80 & 90 & 100 \\
\hline \multirow[t]{11}{*}{ C. $s$} & 1 & $120<$ & 90 & 30 & 30 & 15 \\
\hline & 2 & $120<$ & 90 & 30 & 30 & 15 \\
\hline & 3 & $120<$ & 90 & 30 & 30 & 15 \\
\hline & 4 & $120<$ & 90 & 30 & 30 & 15 \\
\hline & 5 & $120<$ & 60 & 30 & 30 & 10 \\
\hline & 6 & $120<$ & 30 & 30 & 10 & 10 \\
\hline & 7 & $120<$ & 30 & 30 & 10 & 10 \\
\hline & 8 & $120<$ & 30 & 30 & 10 & 10 \\
\hline & 9 & $120<$ & 90 & 30 & 15 & 10 \\
\hline & 10 & $120<$ & 90 & 30 & 10 & 10 \\
\hline & $\overline{\mathbf{X}}$ & 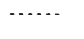 & 69.0 & 30.0 & 20.5 & 12.0 \\
\hline \multirow[t]{11}{*}{ C. $c$} & 1 & $120<$ & 60 & 30 & 30 & 10 \\
\hline & 2 & $120<$ & 60 & 30 & 30 & 10 \\
\hline & 3 & $120<$ & 60 & 30 & 30 & 10 \\
\hline & 4 & $120<$ & 30 & 30 & 10 & 15 \\
\hline & 5 & $120<$ & 30 & 30 & 10 & 10 \\
\hline & 6 & $120<$ & 30 & 30 & 10 & 10 \\
\hline & 7 & $120<$ & 30 & 30 & 15 & 10 \\
\hline & 8 & $120<$ & 30 & 60 & 10 & 10 \\
\hline & 9 & $120<$ & 30 & 30 & 10 & 10 \\
\hline & 10 & $120<$ & 30 & 30 & 10 & 10 \\
\hline & $\overline{\mathrm{X}}$ & $\ldots \ldots$ & 39.0 & 33.0 & 16.5 & 10.5 \\
\hline \multicolumn{2}{|c|}{ C. carrionii } & $120<$ & 60 & 30 & 15 & 10 \\
\hline
\end{tabular}

C. $s:$ C. sphaerospermum C. $c:$ C. cladosporioide

湿熱抵抗性を示した。

3 乾熱抵抗性試験：C. $s$ の場合, 乾熱処理による平 均死减時間は, $70^{\circ} \mathrm{C} て ゙ 69.0$ 分, $80^{\circ} \mathrm{C}$ で30.0分, $90^{\circ} \mathrm{C}$ で
22.5分， 100 Cで12.0分であった（Table 2)。一方 C. $c$ は, 70 Cでは39.0分，と他種に比較してもっとも高い乾 熱感受性を示し，それ以降 $80^{\circ} \mathrm{C} て ゙ 33.0$ 分， $90^{\circ} \mathrm{C}$ で 16.5 分, 100 Cで9.5分であった。またC. carrionii は70 C で60分, $80^{\circ} \mathrm{Cで30八,} 90^{\circ} \mathrm{C} て ゙ 15$ 分, $100^{\circ} \mathrm{C} て ゙ 10$ 分の死滅 時間であった.このように乾熱抵抗性においても種差が 認められ, $70,90,100^{\circ} \mathrm{C}$ 各処理温度では供試した 3 菌種のらちC. sが最も高い乾熱抵抗性を示した。

\section{考葟}

バリア環境下の実験動物施設では, 各種消毒薬を用い た化学的方法やェアフィルター, 紫外線殺菌灯といった 物理的方法により微生物コントロールが行なわれてい る. しかしながら C. s, C. c をはじめとする腐生真菌 は, 空中菌や土壤菌としての分布頻度も高く $[1,6,17]$, 動物入荷時や使用器具への付着などにより, バリア区域 内に持ち込まれる機会が多いことから，各殺菌法の特性 を活かしたより効果的な実施が必要とされる.

一般に細菌, 真菌は增殖最適温度により区分される が, 真菌では細菌ほど高温域で増殖するるのは少ない傾 向にある. 真菌の場合, 增殖最適温度が $35 \sim 53^{\circ} \mathrm{C}$ のの を高温性菌, $25 \sim 45^{\circ} \mathrm{C}$ の のを中温性菌, $5 \sim 25^{\circ} \mathrm{C}$ の のを低温性菌と区分される [18]。今回の恒温増殖性試 験では C. s, C. $c$ 両種とも中温性菌の增殖温度域内に あたが，C. $c$ は $30^{\circ} \mathrm{C}$ 以上になると発育が悪く，集落の 小型化も明らかであることから，C. $c$ が高温域での增 殖性に欠け，C. $s$ より最適增殖温度域の狭いことが推 
察された。

芝崎 $[8,9]$ および高鳥 $[13,14,15]$ は数種の腐生 真菌を用いて熱抵抗性試験を実施している. そのなかで 湿熱処理温度を $52{ }^{\circ} \mathrm{C}$ 設定した際, C. $c$ は 2 分以内に 死隇すると報告されている。今回の試験に用いた実験動 物施設由来株でも $C . s$ は $48^{\circ} \mathrm{C}, C . c$ は $43^{\circ} \mathrm{C} て ゙$ 湿熱抵抗

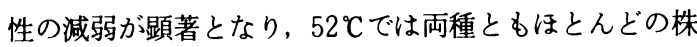
で，1 分以内の死隇が確認された。これは先の報告とほ ぼ同様の効果であった。また他の中温性腐生真菌では湿 熱処理温度を $52^{\circ} \mathrm{C}$ 設定した場合, Aspergillus niger, Fusarium oxysporumについては15分以上の処理で 死减, Penicillium citrinum, Mucor mucedo, Rhi zopus stoloniferついて60分処理でも菌は生残するこ とが, 報告されている。これらのことから, 今回供試し た両種は, 中温性菌のなかでも湿熱抵抗性の弱い種であ り, 特に C. c はより低い湿熱処理で容易に死隇するこ とが示唆された。

乾熱による殺カビ効果は湿熱処理にくらべ著しく効果 が弱く，その効果も種によりかなり異なることが知られ ている[13]。つまり, Aspergillus fumigatus, Eurotium chevalieri, Absidia corymbifera, Mucor mucedoにおいては $100^{\circ} \mathrm{C}, 90$ 分の乾熱処理に抵抗する が, Alternaria, Aureobasidium, Cladosporium, Geotrichum, Trichoderma, Phomaなどの好湿性菌 は, $80^{\circ} \mathrm{C}$ 程度の処理で比較的早期に死堿する。今回供試 した C. $s, C . c$ は, $80^{\circ} \mathrm{C}$ 処理で30分までは抵抗性を示 したが, それ以降温度上昇に伴って, 死減時間の短縮が 認められた。これらのことから両種は, 他の腐生真菌と 比較し乾熱抵抗性においても弱い種であり, 特に $C . c$ はその傾向が顕著であると考えられた。

以上の結果から実験動物施設由来の C. $s$ 扰よび C. $c$ は他の腐生真菌に比較して熱抵抗性の弱い菌種であり, 特に C. $c$ は $C . s よ り$ 高温域での発育も悪く, 湿熱およ び乾熱処理に対して高い感受性を示すことが明らかとな った。従って, 両菌種に対しては熱処理が非常に有効な 防御手段と考えられ， $50^{\circ} \mathrm{C}$ 以上 15 分の湿熱処理，または $90^{\circ} \mathrm{C}$ 以上, 20 分の乾熱処理が最も効果的であると示唆さ れた。

\section{要的}

実験動物飼育施設由来の腐生真菌 Cladosporium に ついて熱抵抗性試験を実施した。恒温培養增殖性試験に おいて, C. sphaerospermum (C. c) および C. cladosporioides (C. c) は, $25 \sim 32{ }^{\circ} \mathrm{C}$ では発育したが, $35^{\circ} \mathrm{C}$
以上では発育しなかった。両種とも集落の直径は, 培養 温度の上昇に伴って小さくなる傾向を示し，その程度は C. $s$ に比較して C. $c$ の方が顕著であった。湿熱抵抗性 試験において, C. $s$ は $48^{\circ} \mathrm{C}, 12$ 分, C. $c$ は $43^{\circ} \mathrm{C}$, 約 26 分の処理で死減し, $55^{\circ} \mathrm{C}$ 以上の処理では両種とも1 分以 内に死隇した。乾熱抵抗性試験では, $70 \sim 100^{\circ} \mathrm{C}$ の処理 において，C. $s$ は 69〜12分，C. $c$ は39〜9.5分で死堿し た。以上の結果から C. $s$ 扰よび $C . c$ は他の腐生真菌に 比較して熱抵抗性の弱い菌種であり, 特に C. $c$ は $C . s$ よりもその傾向が明らかであった。従って両種に対する 熱処理は, 実験動物施設内における有効的な防徽対策法 であると示唆された。

\section{文献}

[1] George, L. B. (1986). Cladosporium Link. In The Genera of Hyphomycetes from Soil, pp 128-130, The Williams and Wilkins Company., Baltimore.

［2］井上富士男.（1987）.工場に拈ける微生物制御，防菌・ 防徽. 1, 78-82.

[3] 以上真由美. (1979). 建物のカビ. pp 9-36. 日本建築 士会連合会, 東京.

[4] Leventin, E. and Horowitz, L. (1978). A one year survey of the airborne molds of tulsa. Oklahoma Animal of allergy, 41, 21-27.

［5］日本工業規格。（1981）。功抵抗性試験法．pp 4, 日本 規格協会, 東京

[6] Robert, A. S., Ellen, S. H., and Connie, A. N. (1981). Cladosporium Link ex Fr. In Introduction to FoodBorne Fungi, pp 175-182, Centraalbureau voor schimmelcultures., Netherland.

[7] Barnett, H. L., Beneke, E. S., Emerson, R., Farr, M. L., Gray, W. D., Korf, R. P., and Simmons, E. G. (1974). Sampling airborn fungi. In Mycology Guide Book, pp. 379-383, Russell, B. S. (edit.), University of Washington Press Inc., Seattle and London.

［8］芝崎 熟（1985）。微生物の制御とその基礎．防菌・防 微, 13, 525-534

［9］芝崎 勲（1985）. 微生物の制御とその基礎。防菌・防 徽, 13, 569-580

[10］高鳥浩介（1982）. 畜産に批るカビ(4). 畜産の研究. 図附.

［11］高鳥浩介(1983). 真菌の同定．微生物同定法．pp 197239. 衛生技術会編. 東京。

[12］高鳥浩介・石井喜一・鉿木文子・村山晶子・中尾美津男 (1983). 食品工場を污染するカビの研究. 防菌・防徽, 11, $463-468$.

[13］高鳥浩介（1986）. 食品環境における物理的処理におけ る真菌制御，特に温度処理による殺カビ性について．伊 藤記念財団・食肉に関する助成研究成果報告書. 4, 1-8。

[14]高鳥浩介 (1988). 败生物の各種抵抗性, 3, 真菌. 実験 動物施設における滅菌・消毒マニュアル．pp 120. 前島 一淑, 浦野徹, 佐藤 浩, 八神健一編。ソフトサイエ ンス社, 東京

[15］高鳥浩介（1988）．防カビ試験と防カビ対策．医薬ジャ 一ナル. 1, 78-82.

[16］山内忠平 (1986). 実験動物の環境と管理 pp 122-123 出版科学棇合研究所, 東京. 
［17］宇田川俊一・椿 啓介編（1978）. 菌類四鑑・上. 空中 菌類. pp 51-63. 講談社, 東京.

［18］宇田川俊一－（1983）. 最新食品物生物制御システムデー
夕集. $\mathrm{pp}$ 113. 春田三佐, 宇田川俊一, 横山理雄編

サイェンスフォーラム, 東京。 